\title{
Fluorescence In Situ Hybridization-Based Approaches for Detection of 12p Overrepresentation, in Particular i(12p), in Cell Lines of Human Testicular Germ Cell Tumors of Adults
}

\author{
M. M. C. Mostert, M. van de Pol, J. van Echten, D. Olde Weghuis, \\ A. Geurts van Kessel, J. W. Oosterhuis, and L. H. J. Looijenga
}

\begin{abstract}
Overrepresentation of the short arm of chromosome 12 is frequently detected in human testicular germ cell tumors of adolescents and adults (TGCT). This overrepresentation mostly results from the formation of an isochromosome: $i(12 p)$. Whether the overrepresentation consistently involves the complete $12 \mathrm{p}$ arm including the centromere is still unclear. We studied five TGCT-derived cell lines (NT2, 2102Ep, H12.1, NCCIT, and S2), combining conventional chromosome banding, fluorescence in situ hybridization (FISH), and comparative genomic hybridization (CGH) to investigate the suitability of each of these techniques to detect aberrations involving chromosome 12. Karyotyping showed one or more i(12p)s in NT2, 2102Ep, H12.1, and S2. However, FISH with a centromere-specific probe (pa12H8), a 12p "paint" and a 12p11.2-p12.1 region-specific probe yeast artificial chromosome (YAC) \#5 and CGH could not confirm the presence of an $1(12 p)$ in S2. Additional randomly distributed $12 p$ sequences were detected by FISH in H12.1, NCCIT, and S2. In most of these cases, (a part of) the centromere was included. All overrepresented $12 p$ regions, except for those in S2, showed hybridization with YAC\#5. CGH showed increased copy numbers of the complete $12 p$ am in the cell lines wilh one or more i(12p)s but no overrepresentation was noted in the cell lines without i(12p). In metaphase spreads, the centromeric block of the i(12p)s differed in size as compared with those of normal chromosomes 12. This was rarely noted in interphase nuclei. A decrease in size of the centromeric block in 2102Ep and H12.1 caused a weak FISH signal, which was difficult to detect, especially in interphase nuclei. The ratio between pa12Hi- and YAC\#5-derived signals reflected the presence or absence of one or more i(12p)s. Our results indicate that double FISH with a centromere- and a $12 p$-specific probe can be used to detect $12 p$ overrepresentation [including $1(12 p)$ ] in TGCT both in metaphase spreads and interphase nuclei. CGH confirmed the relative overrepresentation of $12 p$ sequences as detected by FISH and showed that in these cell lines the complete $12 p$ was involved.
\end{abstract}

\section{INTRODUCTION}

Human testicular germ cell tumors of adolescents and adults (TGCT) can clinically and histologically be grouped

From the Laboratory for Experimental Patho-Oncology Dr. Daniel den Hoed Cancer Center, University Hospital Rotterdam (M. M. C. M., M. vd P., J. W. O., L. H. J. L.), Rulterdan; Depurtment of Medical Genetics University Hospital Groningen ( $J$. $v$ E.), Groningen; and Departmert of Human Genetics, University Hospital Nijmegen, (D. O. W., A. G. v K.), Nijmegen, The Netherlands. Address reprint requests to: $M$. M. C. Mostert, Laboratory for Experimental Patho-Oncology, Dr. Daniel den Hoed Cancer Center, Groene Hilledijk 301, 3075 EA Rotterdam, The Netherlands.

Received July 5, 1995; ascepted August 15, 1995. into two entities; the seminomas (SE) and nonseminomatous TGCT (NS) [1,2]. All TGCT originate from a common precursor, carcinoma in situ (CIS) [3]. Despite a hypertriploid DNA content for CIS and SE and a hypotriploid DNA content for NS [4-6], they show a striking similarity in chromosome constitution [7], supporting a common pathogenetic origin. The only recurrent chromosome abnormality detected both in SE and NS by conventional karyotyping is an isochromosome of the short arm of chromosome 12 [i(12p)], present in $\sim 70 \%$ of all TGCT [8]. The presence of an $i(12 p)$ is sufficiently specific to classify a cancer of the male gonad as a TGCT $[9,10]$. In addition, the number of copies of $\mathrm{i}(12 \mathrm{p}) \mathrm{s}$ has been suggested to be a prognostic 
parameter $[11,12]$. Cytogenetically, TGCT without i(12p) show significantly more breakpoints in the $12 \mathrm{p} 13$ band as compared with those with $\mathrm{i}(12 \mathrm{p})[8,13]$.

Recently, fluorescence in situ hybridization (FISH), which can be applied on metaphase spreads as well as on interphase nuclei ("interphase cytogenetics"), was introduced [14-17]. This technique confirmed the genuine nature of the $\mathrm{i}(12 \mathrm{p})$ in TGCT $[18,19]$ and showed that all i(12p)-negative TGCT tested so far contained additional $12 p$ sequences $[13,20]$, implying that relative overrepresentation of $12 p$ sequences is crucial for the development of a clinically manifest TGCT. FISH on interphase nuclei with a centromere-specific probe for chromosome 12 has been used to identify TGCT $[11,21]$, based on a consistent size difference between the hybridizing centromeric region of the isochromosome and the normal chromosome 12 homologues. The reliability of this method depends on the consistent involvement of centromeric sequences in the formation of $i(12 p)$. TGCT without size differences of the centromeric regions of the chromosomes 12 and their derivatives, including the "i(12p)-negative" TGCT, will not be recognized by this approach.

We used the combination of chromosome banding and FISH on metaphase spreads to study overrepresentation of centromeric and 12p sequences in five TGCT cell lines. The results were compared with the findings on interphase nuclei. In addition, we used the comparative genomic hybridization (CGH) technique $[22,23]$ to study the presence of $12 p$ nverrepresentation in these cell lines.

\section{MATERIALS AND METHODS}

\section{Cell Lines}

We analyzed five established TGCT-derived cell lines, three derived from NS (i.e., NT2 [24], 2102Ep [25], and H12.1, a gift from H.-J. Schmoll, Hannover, Germany) and two cell lines reported to show SE-like characteristics (i.e., NCCIT [26] a gift from I. Damjanov, TX, U.S.A.) and S2 (a gift from A. von Keitz, Marburg, Germany). The cell lines were cultured by conventional methods $\left(37^{\circ} \mathrm{C}, 5 \% \mathrm{CO}_{2}\right)$ in culture flasks (Costar, Cambridge, England) and passaged every 2-4 days by trypsinization, depending of the growth rate of each individual cell line.

\section{Slide Preparation for Conventional Chromosome Banding and FISH}

Cell suspensions for generation of metaphase spreads of the five cell lines were prepared according to standard procedures. The mitotic cells were harvested after 2-4 h of Colcemid (Life Technologies, NY, U.S.A.) treatment, swollen in hypotonic KCl solution, and fixed with methanol: acetic acid fixative.

For conventional karyotyping, air-dried preparations were banded with pancreatin (Sigma, St. Louis, MO, U.S.A.) as reported previously [27]. The chromosome constitution is described according to the International System for Human Cytogenetic Nomenclature [28], except that it is calculated on the basis of a triploid instead of a diploid DNA content because of the consistent peritriploid DNA content of TGCT $[4,7]$.
The slides used for the combination of GTG-banding and FISH were prepared as reported previously [29], with some modifications. Air-dried slides were incubated overnight at $60^{\circ} \mathrm{C}$. During the first minutes, the temperature was continuously raised from room temperature to the final temperature. Subsequently, the slides were washed in $2 \times$ SSC for $1.5 \mathrm{~h}$. After a single wash in $0.85 \% \mathrm{NaCl}$, the slides were digested for 1-5s at room temperature with $0.25 \%$ trypsin (Difco, Brunschwig, Amsterdam, The Netherlands) in the same buffer. After two washes in $0.85 \%$ $\mathrm{NaCl}$, they were stained for 3 min with Giemsa, according to the manufacturer's recommendations (Brunschwig Chemie, Amsterdam, The Netherlands). The slides were washed twice and air dried. Metaphases of inlerest were photographed with an Axiophot microscope (Zeiss, Weesp, The Netherlands) and then destained in 70\% ethanol for 15 min at room temperature and directly used for FISH.

\section{Generation and Labeling of the Probes for FISH}

To obtain a suitable $12 p$ "paint" for FISH, i(12p)s from the cell line NT2 were flow sorted, amplified, and biotin labeled by degenerated oligonucleotide primed (DOP)-polymerase chain reaction (PCR) as previously described [30]. In addition, a yeast artificial chromosome (YAC)\#5 (a gift from Dr. R. Gemmill, Denver, CO, U.S.A.), mapped to chromosome region 12 p11.2-p12.1 [23] was used. This YAC, $\sim 300$ kilobases (kb) long, was purificd by pulse-field gel elcctrophoresis and amplified by DOP-PCR (38 cycles) as descrihed previously [31]. Suhsequently, the DNA was labeled with biotin-14-dUTP (GIBCO-BRL, Gaithersburg, MD, U.S.A.) in a second round of amplification (30 cycles) under the same conditions, except that the dTTP concentration was reduced to half. The centromeric region of chromosome 12 was visualized with probe $\mathrm{p} \alpha 12 \mathrm{H} 8$ [32, 33], which was labeled by a standard nick-translation kit (Boehringer, Mannheim, Germany) with biotin-11-dUTP (GIBCO-BRL) for the single and with digoxigenin-11-dUTP (Boehringer) for the double FISH experiments.

\section{FISH}

The labeled probes were dissolved separately in $10 \mu \mathrm{l}$ hybridization mixture (hybmix), $2 \times$ SSC containing $50 \%$ formamid (Merck, Darmstadt, Germany), 10\% dextran sulfate (Pharmacia, Uppsala, Sweden), and $5 \mathrm{mg} / \mathrm{ml}$ herring sperm as carrier DNA in $2 \times \mathrm{SSC}$ (final $\mathrm{pH} 7.0$ ). The probe concentrations in the hybmix were $2 \mathrm{ng} / \mu \mathrm{l}$ for $\mathrm{p} \alpha 12 \mathrm{H8}$ and $20 \mathrm{ng} / \mu \mathrm{l}$ for both the $12 \mathrm{p}$ paint and YAC\#5. FISH was performed as described, previously [14], with some minor modifications. After denaturation $\left(70^{\circ} \mathrm{C}\right.$ for $5 \mathrm{~min}$ in hybmix), the 12p paint and purified YAC\#5 were preannealed with a 25-fold excess of COT-1 DNA (Life Technologies). For the double FISH, the heat-denaturated $\left(100^{\circ} \mathrm{C}\right.$ for 3 min) $p \alpha 12 \mathrm{H} 8$ was added to the hybmix after preannealing of YAC\#5. The denaturated probe mix was added to denaturated slides ( $4 \mathrm{~min}$ in $70 \%$ formamid at $72^{\circ} \mathrm{C}, 2 \times \mathrm{SSC}$, $\mathrm{pH} 7.0$ ) and hybridized for $16 \mathrm{~h}$ (overnight).

The hybrids were visualized with mouse-anti-digoxigenin, tetramethylrhodamine isothiocyanate (TRITC) conjugated rabbit-anti-mouse and TRITC-conjugated goat-antirabbit (all Sigma) or alternating layers of FITC-conjugated 
avidin and biotinylated goat-anti-avidin antibodies (Vector Laboratories, Burlingame, CA, U.S.A.). Finally, the slides were mounted in antifade ( $p$-phenylenediamine dihydrochloride, 90\% glycerol, $\mathrm{pH}$ 8.0), supplemented with 4,6diamino-2-phenylindolo (DAPI, Sigma) (final concentration $1 \mu \mathrm{g} / \mathrm{ml}$ ) for counterstaining of the chromosomes. Results were studied with a Zeiss Axiophot epifluorescence microscope, equipped with appropriate filters for the visualization of FITC, TRITC, and DAPI fluorescence. Representative photographs were made conventionally or with a Photometrics high-performance CH250/A cooled CCD-camera (Photometrics, Tucson, AZ, U.S.A.). The final figures were generated with a Macintosh Quadra 950 computer using the BDS-image FISH software package (Oncor, Gaithersburg, MD, U.S.A.).

\section{Screening and Interpretation}

The karyotypes were interpreted by an experienced cytogenetic technician unaware of the FISH results. FISH results were scored separately by two individuals. For each experiment, 25 metaphases and 100 interphase nuclei were counted. Signal distributions per sample were sum- marized as the mean number of spots/metaphase (MNSM) or interphase nucleus (MNSI), and SD was calculated. The differences in sizes of the fluorescent centromeric block of the normal and chromosome 12 derivatives, including i(12p), were also scored. Statistic analysis was performed with the unpaired Student's $t$ test.

\section{CGH}

CGH was performed on conventionally prepared slides for karyotyping as described previously [22, 23, 34, 35]. The metaphases as well as control DNA for the hybridization were obtained from a normal male individual. For each hybridization, $400 \mathrm{ng}$ tumor DNA was labeled with digoxigenin and a similar amount of control DNA was labeled with biotin. COT-1 DNA $80 \mu \mathrm{g}$ (Life Technologies) was added to reduce background signal due to repetitive sequences. After incubation for 2-4 days under a coverslip in a moist chamber, the slides were washed by procedures described for FISH. The hybrids were visualized with FITC-conjugated sheep-antidigoxigenin (Boehringer) (tumor specific signal), and pentamethine cyanine dye isothiocyanate (CY3) conjugated avidin (Jackons, Immuno Research,

Table 1 Modal composite karyotypes of the testicular germ cell tumor derived cell lines studied ${ }^{a}$

\begin{tabular}{|c|c|}
\hline Cell line & Chromosomal constitution \\
\hline NT2 & $\begin{array}{l}56-61, \operatorname{add}(X)(q 24), \operatorname{der}(X) t(X ; 1)(q 13 ; q 11),+\operatorname{der}(X) t(X ; 1)(p 11 ; p 22),-Y, \operatorname{del}(1)(p 36) \\
\text { i(1)(p10), add }(2)(434),-4,-5,-6, \operatorname{add}(6)(\mathrm{q} 25), \operatorname{der}(7) t(7 ; 17)(\mathrm{q} 22 ; \mathrm{q} 21),-8, \operatorname{add}(9)(\mathrm{q} 21) \\
-10, \operatorname{add}(10)(\mathrm{p} 11.1),-11, \operatorname{der}(11) \mathrm{t}(11 ; 15)(\mathrm{q} 11 ; \mathrm{q} 15),+\mathrm{i}(12)(\mathrm{p} 10) \times 2,-13, \operatorname{add}(13)(\mathrm{q} 21) \\
-14,-15,-17,-18,-19, \operatorname{add}(20)(\mathrm{p} 13),-21,-22,-22,+6-8 \operatorname{mar}[\mathrm{cp} 9]\end{array}$ \\
\hline 2102Ep & $\begin{array}{l}51-56, X X,-Y, \operatorname{dup}(1)(q 11 q 21),-2,-3, \operatorname{del}(3)(q 11),-4,-5,-6, \operatorname{dic}(7 ; 9)(q 11.2 ; p 13),-8, \\
\operatorname{add}(8)(\mathrm{p} 11),-9,-9,-10, \operatorname{del}(11)(\mathrm{q} 13 \mathrm{q} 21) \times 2, \operatorname{del}(12)(\mathrm{q} 22),+\operatorname{der}(12) \mathrm{t}(3 ; 12)(\mathrm{q} 11 ; \mathrm{q} 11), \\
+\mathrm{i}(12)(\mathrm{p} 10),-13,-13,-14, \operatorname{add}(14)(\mathrm{p} 11.1),-15, \operatorname{add}(16)(\mathrm{q} 24),-17,-18,-19,-21, \\
-22,-22,+5-10 \operatorname{mar}[\mathrm{cp} 10]\end{array}$ \\
\hline \multirow[t]{3}{*}{ H12.1 } & $\begin{array}{l}\text { Clone A: 52-55,XX,-Y,der(1)t(1;7)(p32;p15), }-2, \operatorname{add}(2)(\mathrm{p} 25),-3, \operatorname{add}(3)(\mathrm{q} 29),-4,-5 \text {, } \\
-6, \operatorname{del}(6)(\mathrm{q} 16), \operatorname{add}(7)(\mathrm{q} 21),-8,-9,-10, \operatorname{add}(10)(\mathrm{p} 15), \operatorname{der}(11) \operatorname{add}(11)(\mathrm{q} 13) \operatorname{del}(11) \\
(\mathrm{p} 15),+\mathrm{i}(12)(\mathrm{p} 10) \mathrm{x} 2,-13, \operatorname{der}(13) \mathrm{t}(13 ; 13)(\mathrm{p} 12 ; \mathrm{q} 12),-14, \operatorname{add}(14)(\mathrm{p} 11),-15,-15,-16, \\
-17, \operatorname{der}(17) \mathrm{t}(11 ; 17)(\mathrm{q} 11 ; \mathrm{p} 12),-18, \operatorname{add}(18)(\mathrm{p} 11.1),-19,-19,-20, \operatorname{der}(20) \mathrm{t}(8 ; 20) \\
(\mathrm{q} 13 ; \mathrm{q} 13),-21,-22,+4-7 \operatorname{mar}[\mathrm{cp} 4]\end{array}$ \\
\hline & $\begin{array}{l}\text { Clone B: 57-59,XX, }+\operatorname{der}(\mathrm{X}) \mathrm{t}(\mathrm{X} ; 10)(\mathrm{q} 25 ; \mathrm{q} 21),-\mathrm{Y}, \operatorname{der}(1) \mathrm{t}(1 ; 7)(\mathrm{p} 32 ; \mathrm{p} 15), \operatorname{dup}(1) \\
(\mathrm{q} 11 \mathrm{q} 21),-2, \text { add(2)(p25),-4,-5, del(6)(q16),+add(7)(q21),-8,add(8)(p11),-9,-9, } \\
-10,-11,-12, \mathrm{i}(12)(\mathrm{p} 10),+\mathrm{i}(12)(\mathrm{p} 10),-13,-13,-14,-14,-15, \operatorname{add}(16)(\mathrm{q} 24),-17, \\
-18,-18,-19,-20,-22,+5-7 \operatorname{mar}[\mathrm{cp} 2]\end{array}$ \\
\hline & $\begin{array}{l}\text { Clone C: } 53-57, X X,+\operatorname{der}(X) t(X ; 10)(q 25 ; q 21),-Y, \operatorname{dup}(1)(q 11 q 21),-2,-2,-3,-5,-6 \text {, } \\
\text { add(8)(p11),-9,-9,-10,-11, del(12)(q22),+i(12)(p10) } 22,-13,-13,-14,-15,-18 \text {, } \\
-19,-21,-22,+2-4 \operatorname{mar}[\operatorname{cp} 2]\end{array}$ \\
\hline NCCIT & $\begin{array}{l}53-57, \operatorname{add}(\mathrm{X})(\mathrm{p} 22.1), \operatorname{add}(\mathrm{X})(\mathrm{p} 22.1),-\mathrm{Y}, \operatorname{add}(1)(\mathrm{p} 21), \operatorname{del}(1)(\mathrm{p} 21),+\operatorname{del}(1)(\mathrm{q} 24), \\
+\operatorname{del}(1)(\mathrm{q} 31), \operatorname{add}(3)(\mathrm{q} 11),-4, \operatorname{del}(4)(\mathrm{p} 15.2 \mathrm{p} 15.3),-6, \operatorname{add}(6)(\mathrm{p} 11.2), \operatorname{del}(6)(\mathrm{p} 23),-7, \\
\operatorname{add}(7)(\mathrm{p} 15), \operatorname{del}(7)(\mathrm{q} 11.2),-8, \operatorname{del}(8)(\mathrm{p} 22),-9,-9,-10,-10, \operatorname{add}(11)(\mathrm{p} 11.2), \operatorname{der}(12) \\
\mathrm{t}(9 ; 12)(\mathrm{q} 12 ; \mathrm{q} 12),-13,-14, \operatorname{add}(14)(\mathrm{p} 11),-15, \operatorname{der}(15) \mathrm{t}(15 ; ? ; 15)(\mathrm{p} 11.1 ; ? ; \mathrm{q} 11),-16,-17, \\
-18, \operatorname{der}(19) \mathrm{t}(7 ; 19)(\mathrm{q} 11.2 ; \mathrm{p} 13.1),-20,-21,-22,-22,+\operatorname{der}(?) \mathrm{t}(? ; 1)(? ; \mathrm{p} 13),+\operatorname{der}(?) \\
\mathrm{t}(? ; 10)(? ; \mathrm{q} 11.2),+4-6 \operatorname{mar}[\mathrm{cp} 10]\end{array}$ \\
\hline S2 & $\begin{array}{l}\text { 54-57,X,der(X)t(X;8)(p11;p11),-Y,-1,-1,add(2)(p25)x2,add(2)(p16),-3,-3,add(3) } \\
(\mathrm{q} 11),-4,-4, \operatorname{der}(4) \mathrm{t}(4 ; 12)(\mathrm{p} 13 ; \mathrm{q} 11),-5,-5,-5, \operatorname{add}(6)(\mathrm{q} 11), \operatorname{del}(6)(\mathrm{q} 2 ?),-8, \operatorname{del}(8) \\
(\mathrm{p} 21),-9,-10,-10,-10, \operatorname{der}(11) \mathrm{t}(5 ; ? ; 11)(\mathrm{q} 13 ; ? ; \mathrm{p} 11), \operatorname{der}(12) \mathrm{t}(8 ; 12)(\mathrm{q} 13 ; \mathrm{q} 24) \times 2, \mathrm{i}(12) \\
(\mathrm{p} 10),-13,-14, \operatorname{add}(14)(\mathrm{p} 11),-15, \operatorname{add}(15)(\mathrm{p} 11), \operatorname{der}(15) \mathrm{t}(5 ; 15)(\mathrm{q} 13 ; \mathrm{p} 12),-16,-17, \\
-18,-18, \operatorname{der}(19) \mathrm{t}(1 ; 19)(\mathrm{p} 12 ; \mathrm{p} 13,2),-20, \operatorname{add}(20)(\mathrm{q} 13.3),+\operatorname{add}(21)(\mathrm{p} 12),-22,-22, \\
+\operatorname{der}(?) t(? ; 1)(? ; \mathrm{q} 21),+\operatorname{der}(?) \mathrm{t}(? ; 3)(? ; \mathrm{p} 11),+8-12 \operatorname{mar}[\mathrm{cp} 7)\end{array}$ \\
\hline
\end{tabular}

${ }^{a}$ Descriptions are based on a triploid DNA content. 
West Grove, U.S.A.) (control signal). The results were evaluated with a Zeiss Axiophot epifluorescence microscope, equipped with a Photometrics high-performance CH250/A cooled charge-coupled device (CCD)-camera (Photometrics) connected to a Macintosh Quadra 950 computer using the comparative genomic hybridization applications provided in the BDS-image FISH software package (Oncor). From each cell line, at least 10 metaphase spreads with similar imbalances on both chromatids of both chromosome 12 homologues were interpreted. The individual chromosomes were identified by computer images obtained from the DAPl-banded metaphase chromosomes. Digital analysis allowed representation of the results as fluorescence intensity profile for each fluorochrome along the chromosome. The average green/red ratio was calculated; peaks in the green profile were interpreted as overrepresentation. Photographs were made directly from the computer screen.

\section{RESULTS}

Conventional chromosome banding was performed on five TGCT-derived cell lines. The results are shown in Table 1 as modal composite karyotypes. Three different clones were detected in H12.1. In the context of this study, we focus only on chromosome 12 and related aberrations. NT2, 2102Ep, H12.1, and NCCIT showed at least two normal chromosomes 12. An i(12p) was identified in NT2 (2), $2102 \mathrm{Fp}(1), \mathrm{H} 12.1$ (2) and S2 (1). No i(12p) was noted in NCCIT, but this cell line showed a $\operatorname{der}(12) \mathrm{t}(9 ; 12)(\mathrm{q} 12 ; \mathrm{q} 12)$. S2 contains two $\operatorname{der}(12) \mathrm{t}(8 ; 12)(\mathrm{q} 13 ; \mathrm{q} 24)$ and one $\operatorname{der}(4)$ $\mathrm{t}(4 ; 12)(\mathrm{p} 13 ; \mathrm{q} 11)$, and 2102Ep showed a der(12)t(3;12)(q11; q11) and a del(12)(q22). The latter anomaly was also present in H12.1. Conventional chromosome analysis indicated that three copies of the short arm of chromosome 12 were present in NCCIT, 4 were present in S2, 6 and 7 were present in H12.1, 6 were present in 2102Ep, and 7 were present in NT2. The expected copy numbers of centromeric regions are therefore, $3,3,5,5$, and 5 , respectively.

For the simultaneous detection of centromeric and $12 \mathrm{p}$ sequences, double FISH with p $\alpha 12 \mathrm{H} 8$ and YAC\#5 was performed. In this approach, $\mathrm{p} \alpha 12 \mathrm{H} 8$ was labeled with digoxigenin (detected with TRITC) and the YAC with biotin (detected with FITC). In addition, $\mathrm{p} \alpha 12 \mathrm{H} 8$ labeled with biotin was used in single FISH. The mean numbers of signals per metaphase spread and interphase nucleus (and corresponding SD) of single and double FISH are shown in Table 2. The FISH patterns are shown in Fig. 1 and representative examples are shown in Fig. 2. The results obtained from NT2 and NCCIT confirmed the findings of karyotyping. In contrast, FISH showed that the cytogenetically defined $\mathrm{i}(12 \mathrm{p})$ in S2 contained no chromosome 12derived sequences and was therefore incorrectly identified as such (Fig. 1A). In addition, FISH showed that der(4) $\mathrm{t}(4 ; 12)(\mathrm{p} 13 ; \mathrm{q} 11)$ must be reclassified as $\operatorname{der}(12) \mathrm{t}(4 ; 12)(\mathrm{q} 12$; p11.2)(Fig. 1B).

Despite lack of hybridization of YAC\#5 with one of the chromosome 12 derivatives in $\mathrm{S} 2$, the $12 \mathrm{p}$ paint recognized a small region just proximal to the centromere (Fig.
Table 2 Summary of the single and double FISH results using the centromere-specific probe pa12H8 and YAC\#5 for the 12p11.2-p12.1 subband on metaphases and interphase nuclei of five TGCTderived cell lines

\begin{tabular}{|c|c|c|c|c|}
\hline \multirow[b]{2}{*}{ Cell line } & \multirow{2}{*}{$\frac{\text { Single FISH }}{\mathrm{p} \alpha 12 \mathrm{H} 8}$} & \multicolumn{2}{|c|}{ Double FISH } & \multirow{2}{*}{$\begin{array}{l}\text { Ratio YAC/ } \\
\text { p } \alpha 12 \mathrm{H} 8\end{array}$} \\
\hline & & $\mathrm{p} \alpha 12 \mathrm{H} 8$ & YAC & \\
\hline \multicolumn{5}{|l|}{ NT2 } \\
\hline MNSM & $5.0(0.3)$ & $4.7(0.6$ & $6.7(0.4)$ & 1.4 \\
\hline MNSI & $5.0(1.0)$ & $4.2(0.7)$ & $6.1(0.9)$ & 1.5 \\
\hline \multicolumn{5}{|l|}{$2102 \mathrm{Ep}$} \\
\hline MNSM & $3.9(0.7)$ & $4.0(0.7)$ & $5.8(0.9)$ & 1.5 \\
\hline MNSI & $3.3(0.5)$ & $2.8(0.8)$ & $5.3(1.1)$ & 1.9 \\
\hline \multicolumn{5}{|l|}{$\mathrm{H} 12.1$} \\
\hline MNSM & $4.5(0.6)$ & $4.1(0.5)$ & $5.2(0.6)$ & 1.3 \\
\hline MNSI & $3.9(0.8)$ & $3.4(1.0)$ & $4.3(1.0)$ & 1.3 \\
\hline \multicolumn{5}{|l|}{ NCCIT } \\
\hline MNSM & $2.9(0.5)$ & $2.8(0.7)$ & $2.8(0.8)$ & 1.0 \\
\hline MNSI & $3.3(0.7)$ & $2.7(0.7)$ & $2.8(0.8)$ & 1.0 \\
\hline \multicolumn{5}{|l|}{ S2 } \\
\hline MNSM & $3.0(0.2)$ & $2.9(0.3)$ & $2.0(0.0)$ & 0.7 \\
\hline MNSI & $3.2(0.7)$ & $2.3(0.7)$ & $1.9(0.3)$ & 0.8 \\
\hline
\end{tabular}

Abbreviations: FISH, fluorescence in situ hybridization; MNSM and MNSI, mean number of spots per metaphase and per interphase nucleus; YAC, yeast artificial chromosome.

The centromeric probe was labeled with biotin for the single and with digoxigenin for the double FISH. The MNSM and MNSI as well as corresponding SD (in brackets) are indicated. The ratio between the numbers of YAC- and $\mathrm{p} \alpha 12 \mathrm{H} 8$-derived signals for each cell line is shown.

1B). In addition, in this cell line cryptic $12 p$ sequences were detected in $\operatorname{der}(?) t(? ; 3)(? ; p 11)$ and in the cytogenetically identified add(18)(p11.1) in H12.1. Analysis showed that this latter region also contained a small $\mathrm{p} \alpha 12 \mathrm{H8}$ hybridizing fragment (Fig. $1 \mathrm{C}$ ), as well as a region recognized by YAC\#5 (data not shown). In contrast, no YAC\#5 hybridization was detected in the aforementioned 12pderived region in $\mathrm{S} 2$ (data not shown). The 12p sequences other than those present in normal copies of chromosome 12 and $\mathrm{i}(12 \mathrm{p}) \mathrm{s}$ were distributed randomly throughout the genome, i.e., associated with (parts of) chromosomes 3, 4, $8,9,18$, and 19 .

No size differences between the fluorescent centromeric regions of the normal chromosomes 12 and its derivatives were detected in NCCIT and S2. In contrast, on metaphase spreads, both i(12p)s in NT2 contained an enlarged centromeric region (Fig. 1D), whereas the i(12p)s in 2102Ep and H12.1 contained a smaller hybridizing region. These size differences could only be identified on $<5 \%$ of the interphase nuclei whether biotinylated or digoxigenin-labeled p $12 \mathrm{H} 8$ was used, as illustrated by Fig. 1E, which shows nucleus of NT2 hybridized simultaneously with $\mathrm{p} \alpha 12 \mathrm{H} 8$ and YAC\#5. The appearance of the different signals indicates the presence of three normal chromosomes 12 and two i(12p)s. The po12H8-hybridizing region in add(18) (p11.1) of H12.1 already mentioned and the region present in $\operatorname{der}(12) \mathrm{t}(3 ; 12)(\mathrm{q} 11 ; \mathrm{q} 11)$ of $2102 \mathrm{Ep}$ were reduced in size as compared with their normal homologue (not shown). Despite multiple attempts, the latter centromeric region could be detected by FISH in only $30 \%$ of the metaphase 


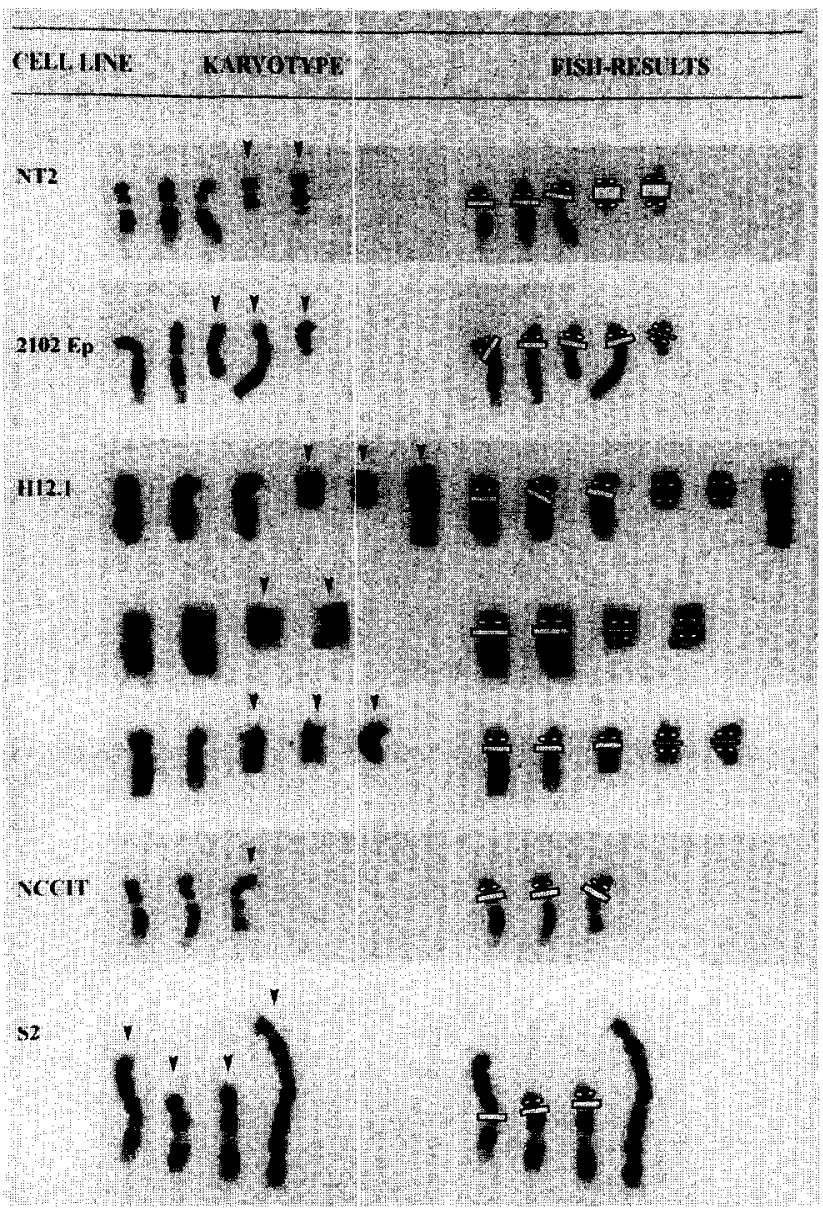

Figure 1 Fluorescence in situ hybridization (FISH) results in chromosome 12 and derivatives (arrow) with the centromeric probe $\mathrm{p} \alpha 12 \mathrm{H} 8$ (indicated by a block) and yeast artificial chromosome (YAC)\#5 (circles).

spreads. Because of the involvement of the centromere of chromosome 12 in this translocation, it must be reclassified as $\operatorname{der}(12) t(3 ; 12)(q 11 ; q 10)$.

In metaphase spreads of 2102Ep, NCCIT, and S2, similar numbers of centromeric regions were detected with the biotinylated and digoxigenin-labeled p $\alpha 12 \mathrm{H8}$ probe (Table 2). Lower copy numbers were observed in NT2 and H12.1 when the latter was compared with the former $(\mathrm{p}<0.05$ and 0.02 , respectively). On interphase nuclei, this decrease in copy numbers was significant in all cell lines $(p<$ 0.001). In general, a lower number of centromeric- and $12 \mathrm{p}$-specific signals was observed on interphase nuclei as compared with metaphase spreads. This was mainly true of the centromeric region in the cell lines showing a reduced size of the fluorescent signal of the chromosome 12 derivatives (2102Ep and H12.1).

Single hybridization with p $12 \mathrm{H} 8$ showed chromosome 12-centromeric regions of more than two in all cell lines tested. Distinction between a normal chromosome 12 , an $\mathrm{i}(12 \mathrm{p})$, or another chromosome 12 derivative could not be made with this approach on interphase nuclei. The simultaneous application of po12H8 and YAC\#5 indicated a relative $12 p$ overrepresentation as compared with the centromeric regions in all three $\mathrm{i}(12 \mathrm{p})$-containing cell lines (NT2, 2102Ep, and H12.1), i.e., ratio of YAC\#5 to p $12 \mathrm{H} 8$ of $\geqslant 1.3$. The cell lines with no $i(12 p)$ (NCCIT and S2) had a ratio of $\leqslant 1.0$.

To study the value of CGH for the detection of 12p overrepresentation in TGCT in romparison to conventional cytogenetic and FISH analysis, CGH was used on the five cell lines included in this survey. The analysis was based on a triploid DNA content of the tumor cells, without contamination of the sample with host cells. No 12 p overrepresentation was detected in the cell lines NCCIT and S2. This finding is in agreement with the combined results obtained by cytogenetic and FISH analyses, showing no more than three copies of the short arm of chromosome 12 in these coll lines. The inability to detect the underrepresentation of $12 p$ sequences in S2, most probably due to the sensitivity of this method, is noteworthy. The other three cell lines (NT2, 2102Ep, H12.1) showed overrepresentation of the complete short arm of chromosome 12 by CGH (shown for NT2 in Fig. 1F), in accordance with the results of cytogenetic analysis combined with FISH, showing six or more copies of $12 \mathrm{p}$ per nucleus.

\section{DISCUSSION}

After the first report of the presence of an i(12p) in TGCT in 1982 [36], multiple studies of this isochromosome were published, dealing with the possible clinical implications [37] as well as different detection methods. The latter include conventional karyotyping, molecular and FISH strategies. Cytogenetically, i(12p) can be detected in most TGCT $[7,38,39]$, supported by molecular data [39, 40]. The FISH approach [11] is based on the use of a centromere specific probe for chromosome 12. This probe has been reported to detect a consistent size difference between the hybridizing region of a normal chromosome 12 and an $\mathrm{i}(12 \mathrm{p})$. Because of a discrepancy in the literature regarding this phenomenon $[18-20,23,41]$, as well as the occurrence of TGCT without $i(12 p)[13,20,42]$, we studied the possibility of identifying $12 \mathrm{p}$ overrepresentation in general, and of $\mathrm{i}(12 \mathrm{p})$ in particular, on metaphase spreads and interphase nuclei with a double FISH approach. In addition, $\mathrm{CGH}$ was applied to investigate whether the entire $12 p$ arm was overrepresented. Because cell lines, in contrast to tumor samples, enable a detailed description of the chromosome constitution and comparison of the data obtained from metaphase spreads and interphase nuclei, five TGCT-derived cell lines were included in this study; three NS (NT2, 2102Ep, and H12.1) and two cell lines reported to be SE-like (NCC.IT and S2). Ours is the first study in which the reproducibility and sensitivity of different methods in detecting chromosome 12 aberrations in TGCTs was tested in detail.

Conventional karyotyping in combination with FISH showed the presence of $\mathrm{i}(12 \mathrm{p})$ in all three NS cell lines but not in the two with a SE-like phenotype, which is of interest because $\mathrm{i}(12 \mathrm{p})$ is more frequently detected in NS as compared with SE; 83 versus $56 \%$ in the largest series of primary TGCT (102) analyzed so far [8]. The aberrant size 

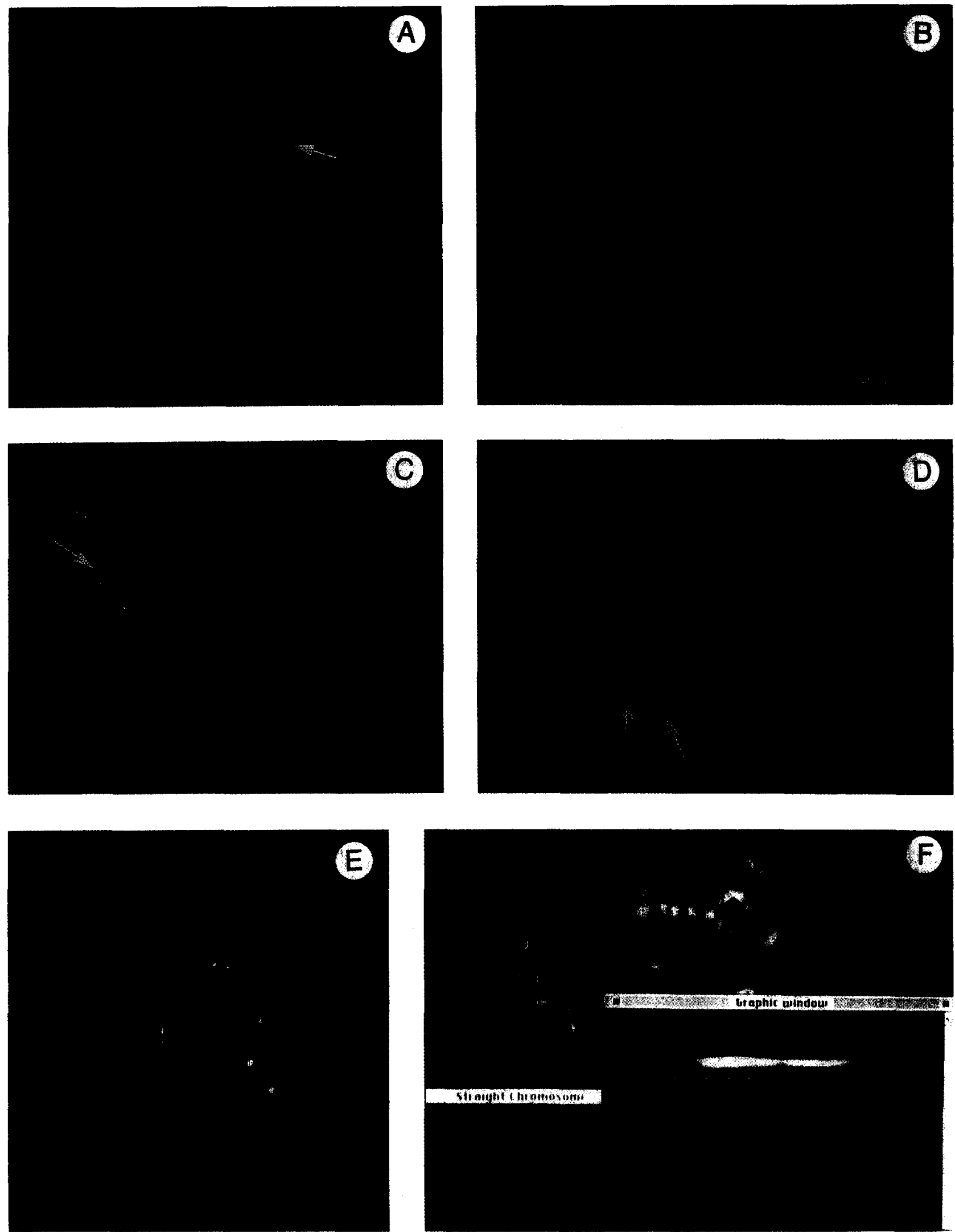

Figure 2 (A) Double fluorescence in situ hybridization (FISH) of a metaphase spread of S2 with the centromerespecific probe p $\alpha 12 \mathrm{H} 8$ (tetramethyl-rodamine isothiocyanate TRITC; red signal) and 12p paint (FITC, yellow signal), and DAPI as counterstaining of the chromosomes: No 12p- or centromere-derived sequences are present on the cytogenetically identified $\mathrm{i}(12 \mathrm{p})$ (arrow), whereas $12 \mathrm{p}$ and centromere sequences are hidden in the cytogeneti- 
of the fluorescent centromeric region of the $\mathrm{i}(12 \mathrm{p})$ as compared with the normal chromosomes 12 detected in metaphase spreads of the cell lines was not observed consistently on interphase nuclei hybridized in the same experiment. Therefore, FISH with only a centromeric region-specific probe is not sufficient to screen for the presence of one or more $i(12 p) s$ in interphase nuclei. This conclusion is strengthened by the fact that in two cell lines (2102Ep and H12.1) a reduced size of the hybridizing centromeric regions was also observed in derivatives of chromosome 12 other than $\mathrm{i}(12 \mathrm{p})$. Therefore, the finding of $\mathrm{i}(12 p)$ in pediatric germ cell tumors, as recently reported [13], must be verified. The double FISH approach used in this study might be informative.

As compared with conventional karyotyping, additional chromosome 12-derived sequences were detected with FISH in H12.1 and S2. All cell lines contained a relative overrepresentation of the centromeric region and short arm sequences of chromosome 12 as compared with their modal chromosome consititution (hypotriploid). CGH showed overrepresentation of $12 p$ sequences only in the cell lines with more than one extra copy of the complete short arm of chromosome 12 [those with at least one $\mathrm{i}(12 \mathrm{p})]$. The ratio of the $12 \mathrm{p}$-derived signals to those reflecting the centromeric regions indicates the presence $(>1.0)$ or absence $(\leqslant 1.0)$ of one or more $\mathrm{i}(12 \mathrm{p}) \mathrm{s}$. This ratio might be useful to study tumors for the presence of the $\mathrm{i}(12 \mathrm{p})$, using interphase cytogenetics. This is currently under investigation. To visualize the presence or absence of $i(12 p)$ on interphase nuclei, a 12p-specific probe mapping closer to the centromere than YAC\#5 would be more informative. Double FISH proved a suitable method for the detection of 12p overrepresentation in general and of $i(12 p)$ in particular on metaphase spreads and interphase nuclei of TGCT-derived cell lines. Currently, we are determining the critical region of overrepresentation of the short arm of chromosome 12 in TGCT using a combination of cytogenetic and FISI I analysis. Hecause CGH confirmed the cytogenetic findings on chromosome 12 of the cell lines included in this study, and because of the recent report of the detection of amplification of a restricted region of the short arm of chromosome 12 in a metastasis of a SE [23], as well as in primary TCICTs [43], we will also use this technique in the analysis of the $12 \mathrm{p}$ aberrations in primary TGCT. This combined approach will finally result in the identification of the chromosome region from which the candidate gene or genes causing development of this cancer can be isolated.
This work was supported by Grant No. NKB-DDHK 94-836 from the Dutch Cancer Society (Koningin Wilhelmina Fonds). We thank Barbara Trask and Ger van de Engh (Department of Molecular Biotechnology, University of Washington, Seattle, WA, U.S.A.) for their contribution concerning the flow-sorted "paint" probe and the purification of YAC\#5 by pulse-field gel electrophoresis and DOP-PCR. We also thank H. Vuik and A. Kievit (Department of Medical Photography, Dr. Daniel den Hoed Cancer Cenler) for their contributions in preparation of the figures. Further, we thank H.-J. Schmoll, I. Damjanov and A. von Keitz for the gift of the cell lines and R. Gemmil for providing YAC\#5. Purchase of the CCD camera and screen for the analysis of the in vitro cultures and of the biohazard flowhood was supported by the Nijbakker-Morra Foundation. We thank the Nijbakker-Morra and Maurits en Anna de Kock Foundation for financial support for purchase of hardware for storage of frozen material.

\section{REFERENCES}

1. Mostofi FK, Sesterhenn IA, Davis CJJ (1987): Immunopathology of germ cell tumors of the testis. Semin Diagn Pathol 4:320-341.

2. Ulbright TM (1993): Germ cell neoplasms of the testis. Am J Surg Pathol 17:1075-1091.

3. Skakkebæk NE, Berthelsen JG, Giwercman A, Müller J (1987): Carcinoma-in-situ of the testis: Possible origin from gonocytes and precursor of all types of germ cell tumours except spermatocytoma. Int J Androl 10:19-28.

4. Oosterhuis JW, Castedo SMMJ, De Jong B, Cornelisse CJ, Dam A, Sleijfer DT, Schraffordt Koops H (1989): Ploidy of primary germ cell tumors of the testis. Pathogenetic and clinical relevance. Lab Invest 60:14-20.

5. El-Naggar AK, Ro JY, McLemore D, Ayala AG, Batsakis JG (1992): DNA ploidy in testicular germ cell neoplasms: Histogenetic and clinical implications. Am J Surg Pathol 16:611-618.

6. De Graaff WE, Oosterhuis JW, De Jong B, Dam A, Van Putten WLJ, Castedo SMMJ, Sleijfer DT, Schraffordt Koops H (1992): Ploidy of testicular carcinoma in situ. Lab Invest 66:166-168.

7. De Jong B, Oosterhuis JW, Castedo SMMJ, Vos A, Te Meerman GJ (1990): Pathogenesis of adult testicular germ cell tumors: A cytogenetic model. Cancer Genet Cytogenet 48: 143-167.

8. van Echten J, Oosterhuis JW, Looijenga LHJ, Wiersma J, te Meerman G, Schraffordt Koops H, Sleijfer DTh, De Jong B (1995): No recurrent structural abnormalities in germ cell tumors of the adult testis apart from i(12p). Genes Chromosomes Cancer 14:133-144.

9. Oosterhuis JW, Looijenga LHJ (1993): The biology of human germ cell tumours: Retrospective speculations and new prospectives. Eur Urol 23:245-250.

10. Gillis AJM, Oosterhuis JW, Schipper MEI, Barten EJ, Van Berlo R, Van Gurp RJHLM, Abraham M, Saunders GF, Looijenga LHJ (1994): Origin and biology of a testicular Wilms' tumor. Genes Chromosomes Cancer 11:126-135.

cally identified der(4)(4;12)(p13;q11) (lower right). (B) Double FISH with pa12H8 (TRITC) and yeast artificial chromosome (YAC\#5) (FITC) on a metaphase spread of S2; there was no hybridization of YAC\#5 with the cytogenetically identified $\operatorname{der}(4) t(4 ; 12)(\mathrm{p} 13 ; \mathrm{q} 11)$ (arrow). (C) FISH with po12H8 (TRITC) and YAC\#5 (FITC) on a metaphase spread of H12.1 showing centromeric region in the add(18)(p11.1) (arrow). (D) Original photograph of a single FISH on a metaphase spread of NT2 with po12H8 (FITC) and propidium iodide as counterstaining of the chromosomes showing enlarged centromeric hybridizing regions of the i(12p)s (arrows) as compared with their normal counterparts. (E) Original photograph of a double FISH with pa12H8 (TRITC) and YAC\#5 (FITC) on an interphase nucleus of NT2 showing three normal chromosomes 12 (one centromeric and one YAC signal) and two i(12p)s (one centromeric and two YAC signals), without size differences of the TRITC-signals. (F) Overrepresentation of the short arm of chromosome 12 in NT2, as detected by comparative genomic hybridization. 
11. Mukherjee AB, Murty VVVS, Rodriguez E, Reuter VE, Bosl G), Chaganti RSK (1991): Detection and analysis of origin of i(12p), a diagnostic marker of human male germ cell tumors by fluorescent in situ hybridization. Genes Chromosomes Cancer 3:300-307.

12. Bosl GJ, Ilson DH, Rodriguez E, Motzer RJ, Reuter VE, Chaganti RSK (1994): Clinical relevance of the i(12p) marker chromosome in germ cell tumors. J Natl Cancer Inst 86:349355.

13. Rodriguez E, Houldsworth J, Reuter VE, Meltzer P, Zhang J, Trent JM, Bosl GJ, Chaganti KSK (1993): Molecular cytogenetic analysis of i(12p)-negative human male germ cell tumors. Genes Chromosomes Cancer 8:230-236.

14. Trask BJ (1991): Fluorescence in situ hybridization: applications in cytogenetics and gene mapping. Trends Genet 7:149154.

15. Price CM (1993): Fluorescence in situ hybridization. Blood Rev 7:127-134.

16. Gray JW, Pinkel D, Brown JM (1994): Fluorescence in situ hybridization in cancer and radiation biology. Radiat Res 137:275-289.

17. Hopman AHN, Voorter CEM, Ramaekers FCS (1994): Detection of genomic changes in cancer by in situ hybridization. Mol Biol Rep 19:31-44.

18. Suijkerbuijk RF, van de Veen AY, van Echten J, Buys C'H, De Jong B, Oosterhuis JW, Warburton DA, Cassiman JJ, Schonk D, Geurts van Kessel A (1991): Demonstration of the geniune iso-12p character of the standard marker chromosome of testicular germ cell tumors and identification of further chromosome 12 aberrations by competitive in situ hybridization. Am J Hum Genet 48:269-273.

19. Suijkerbuijk RF, Looijenga LHJ. De Jong B, Oosterhuis JW. Cassiman JJ, Geurts van Kessel A (1992): Verification of isochromosome $12 \mathrm{p}$ and identification of other chromosome 12 aberrations in gonadal and extragonadal human germ cell tumors by bicolor double fluorescence in situ hybridization. Cancer Genet Cytogenet 63:8-16.

20. Suijkerbuijk RF, Sinke RJ, Meloni AM, Parrington JM, van Echten J, De Jong B, Oosterhuis JW, Sandberg AA, Geurts van Kessel A (1993): Overrepresentation of chromosome 12p sequences and karyotypic evolution in i(12p)-negative testicular germ-cell tumors revealed by fluorescence in situ hybridization. Cancer Genet Cytogenet 70:85-93.

21. Rodriquez E, Mathew S, Mukherjee AB, Reuter VE, Bosl GJ, Chaganti RSK (1992): Analysis of chromosome 12 aneuploidy in interphase cells from male germ cell tumors by fluorescence in situ hybridization. Genes Chromosomes Cancer 5:21-29.

22. Kallioniemi A, Kallioniemi OP, Sudar D, Rutovitz D, Gray JW, Pinkel D (1992): Comparative genomic hybridizalion for molecular cytogenetic analysis of solid tumors. Science 258:818-820.

23. Suijkerbuijk RF, Sinke RJ, Olde Weghuis DEM, Roque L, Forus A, Stellink F, Siepman A, Van de Kaa C, Soares J, Geurls van Kessel A (1994): Anplification of chromusune subregion 12p11.2-p12.1 including PTHLH in a metastatis of an $\mathrm{i}(12 \mathrm{p})$-negative seminoma: Relationship to tumor progression? Cancer Genet Cytogenet 78:145-152.

24. Andrews PW (1984): Pluripotent embryonal carcinoma clones derived from the human teratoma cell line Tera-2; Differentiation in vivo and in vitro. Lab Invest 50:147-167.

25. Wang N, Perkins KL, Bronson DL, Fraley EE (1981): Cytogenetic evidence for premeiotic transformation of human testicular cancers. Cancer Res 41:2135-2140.

26. Damjanov 1, Horvat B, Gibas Z (1993): Retinoic acid-induced differentiation of the developmentally pluripotent human germ cell tumor-derived cell line, NCCIT. Lab Invest 68:220-232.
27. Wang HC, Fedoroff S (1972): Banding in human chromosomes treated with trypsin. Nature 235:52-54.

28. ISCN (1991): Guidelines for Cancer Cytogenetics. Supplement to An International System for Human Cytogenetic Nomenclature, Mitelman F, ed. Karger, Basel.

29. Smit VTHBM, Wessels JW, Mollevanger P, Schrier PI, Raap AK, Beverstock CC, Cornelisse CJ (1990): Combined GTGbanding and non-radioactive in situ hybridization improves characterization of complex karyotypes. Cytogenet Cell Genet $54: 20-23$

30. Blennow E, Telenius H, Larsson C, De Vos D, Bajalica S, Ponder BAJ, Nordenskjold M (1992): Complete characterization of a large marker chromosome by reverse and forward chromosome painting. Hum Genet 90:371-374.

31. Telenius H, Carter NP, Bebb CE, Nordenskjold M, Ponder BA, Tunnacliffe A (1992): Degenerate oligonucleotide-primed PCR: General amplification of target DNA by a single degenerate primer. Genomics 13:718-725.

32. Looijenga LHJ, Smit VTHBM, Wessels JW, Mollevanger P, Oosterhuis JW, Cornelisse CJ, Devilee P (1990): Localization and polymorphism of a chromosome 12-specific $\alpha$ satellite DNA sequence. Cytogenet Cell Genet 53:216-218.

33. Looijenga LIHJ, Oosterhuis JW, Smit VTHIBM, Wessels JW, Mollevanger P, Devilee P (1992): Alpha satellite DNA on chromosomes 10 and 12 are both members of the dimeric suprachromosomal subfamily, but display little identity at the nucleotide sequence level. Genomics 13:1125-1132.

34. Forus A, Olde Weghuis D, Smeets D, Fodstad O, Mykebost O, Geurts van Kessel A (1995): Comparative genomic hybridization of human sarcomas: I. Occurrence of genomic imbalances and identification of a novel major amplicon at 1q21-q22 in soft tissue sarcomas. Genes Chromosomes Cancer 14:8-12.

35. Forus $\Lambda$, Olde Weghuis D, Smeets D, Fodstad O, Myklebost O, Geurts van Kessel A (1995): Comparative genomic hybridization analysis of human sarcomas: II. Identification of novel amplicons at $6 p$ and $17 p$ in osteosarcomas. Genes Chromosomes Cancer 14:15-21.

36. Atkin NB, Baker MC (1982): Specific chromosome change, i(12p), in testicular tumours? Lancet 8311:1340.

37. Chaganti RSK (1990): Isochromosome of chromosome 12: Clinically useful marker for male germ cell tumors. Response. J Natl Cancer Inst 82:1433.

38. Oosterhuis JW, Castedo SM, De Jong B (1990): Cytogenetics, ploidy and differentiation of human testicular, ovarian and extragonadal germ cell tumours. Cancer Surv 9:320-332.

39. Samaniego F, Rodriguez E, Houldsworth J, Murty VV, Ladanyi M, Lele KP, Chen QG, Dmitrovsky E, Geller NL, Reuter V, et al. (1990): Cytogenetic and molecular analysis of human male germ cell tumors: Chromosome 12 abnormalities and gene amplification. Genes Chromosomes Cancer 1:289-300.

40. Peltomäki P, Lothe RA, Børresen AL, Fosså SD, Brøgger A, de la Chapelle A (1992): Chromosome 12 in human testicular cancer: Dosage changes and their parental origin. Cancer Genet Cytogenet 64:21-26.

41. Geurts van Kessel A, Suijkerbuijk RF, Sinke RJ, Looijenga L, Oosterhuis JW, De Jong B (1993): Molecular cytogenetics of human germ cell tumours: $\mathrm{i}(12 \mathrm{p})$ and related chromosomal anomalies. Eur Urol 23:23-29.

42. Castedo SMMJ, De Jong B, Oosterhuis JW, Seruca R, Idenburg VJS, Buist J, Sleijfer DT (1988): "i(12p) negative" testicular germ cell tumors. A different group? Cancer Genet Cytogenet 35:171-178.

43. Mostert, MMC, van de Pol M, Olde Weghuis D, Suijkerbuijk RT, Geurts van Kessel A, van Echten J, Oosterhuis JW, Looijenga LHJ (1996): Comparative genomic hybridization of germ cell tumors of the adult testis: Confirmation of karyotypic findings and identification of a $12 \mathrm{p}$-amplicon. Cancer Genet Cytogenet (in press). 